\title{
The main ways of implementing gaming technologies in the process of career guidance work for choosing the profession of an engineer
}

\author{
Svetlana Ovchinnikova ${ }^{1,{ }^{*}}$, Elena Schneider $^{2}$, Elena Tamoshkina ${ }^{2}$, and Irina Gadzhialieva ${ }^{2}$ \\ ${ }^{1}$ I. T. Trubilin Kuban State Agrarian University, 350012, Krasnodar, Russia \\ ${ }^{2}$ Nevinnomyssk State Humanitarian and Technical Institute, 357108, Nevinnomyssk, Russia
}

\begin{abstract}
The paper considers play as a teaching method in career guidance activities of high school students and believe that play is most adequate in career guidance work, because with its help various kinds of students' initiatives can be implemented, which is extremely important for this process. And from this position, play cannot be separated from activity and must be considered as a way of realizing it. Didactic research establishes not only the content, essence, signs, characteristics and features of certain processes, factors, phenomena, but also the conditions for their effective functioning. The main purpose of career guidance work is to form the professional orientation of students, to provide them with assistance and support in the process of self-determination when choosing. If career guidance work is carried out in the learning process, then it is of a specific nature. Its main feature is the close connection of the acquired theoretical knowledge with individual skills and possible skills that may be required in the process of professional activity, as well as with possible objects and tools of labor. For this it is necessary to simulate the possible future components of a particular profession, and all these components must be properly organized. Gaming technologies help in this issue.
\end{abstract}

\section{Introduction}

The scale and density of the information flow accelerates the process of obsolescence of the theoretical base, which forms the readiness of an individual for professional activity at the stage of studying in a secondary school [1-3].

Active processes of development of market economic relations in all spheres of activity of Russians have aggravated the situation on the domestic labor market. The situation of competition between specialists has formed new factorial conditions for employment.

In modern conditions, a special situation has developed with the training of technical specialists [4], since the interest of the younger generation in the profession of engineer has significantly dropped in the last twenty years [5-7]. And without the return of the due high prestige to engineering work, the successful further development of our society and production seems to be quite problematic.

* Corresponding author: Svetlana.swetlana-ov@yandex.ru 
Engineering activity in modern conditions is becoming extremely complex and differentiated, as a result of which the requirements for the personality of a technical profile are significantly increased: new knowledge, innovative thinking, developed professionally significant qualities are needed [8-9].

Considering that the foundation of engineering education is the subjects of the physical and mathematical cycle, as well as technical drawing, the need to identify the psychological and pedagogical conditions for improving the educational process in both secondary and higher education, aimed at improving the correct professional and social choice of graduates of secondary schools related to technical activities, becomes obvious.

In the school of the city of Nevinnomyssk, in which a formative experiment in the implementation of gaming technologies in the process of career guidance work for choosing the profession of an engineer was carried out, two school-wide programs "World of Professions" and also "Abilities and Talent" were used [10].

The formative experiment was carried out within the framework of programs for the development of content, forms and methods of career guidance activities. Among the tasks of the programs, there are increasing the level of needs among children in choosing a profession, developing social self-determination, forming attitudes among high school students for specific professions, including class teachers in career guidance activities, the activities of a social teacher, a psychologist on the problems of developing students' abilities, and assistance of subject teachers in the popularization of those professions.

\section{Methods and materials}

The content of the program included several blocks: conducting conversations and lectures to teach students information and reference material about those professions that are significant for the North Caucasus region.

The second block included school-wide and classroom activities for career guidance, the activities of various associations and circles in this area. The third block was a combination of various gaming technologies that were designed to stimulate the activity of students and teachers in the process of career guidance.

The whole school, methodological associations, teachers, and homeroom teachers took part in the implementation of the programs.

For example, among the events of the program "World of Professions", included in the general school plan of educational work and implemented in the future in the process of working with senior students, were:

1. Conducting months in subjects:

- mathematics and physics;

- Russian language and literature;

- native language;

- drawing;

- biology, chemistry, geography, ecology;

- life safety, physical education;

- foreign language.

2. Teaching schoolchildren to use reference career guidance literature.

3. Conducting school Olympiads.

4. Homeroom periods "World of Professions".

5. Involvement of students in creative groups and sports teams.

6. School-wide event "Festival of Professions".

7. Drawing competition "My favorite profession".

8. Exhibition of arts and crafts of high school students "Miracles made with your own hands". 
9. Competition "Defense of the Profession" (in the form of a game presentation of the chosen profession by senior students).

10. Games assembly of Olympiad winners and academic excellence. There were many events that are aimed to work with parents. Let's name some of them:

1. examination of the conditions for the professional education of children;

2. organization of individual consultations for parents;

3. listening to parents at meetings about career guidance work in the family;

4. diagnostics of career guidance "Your life choice";

5. conducting a lesson for parents "The role of play in the life of a student".

The program provided for a lot of things and activities aimed at increasing the career guidance competence of teachers:

1. scheduling the work of subject groups;

2. reports on the professional self-education of school teachers;

3. holding a meeting of the methodological council "Testing as a method of career guidance diagnostics";

4. meeting of the School of Young Teachers;

5. attending extracurricular activities in the subject;

6. attendance at conferences, methodological seminars, thematic consultations of working teachers on the problems of professional advice for high school students; $-11)$;

7. adjusting the programs of optional courses (grades 9) and elective courses (grades 10

8. holding the Open days;

9. using tests, crosswords in groups;

10. survey of parents and children on the topic "In the world of professions";

11. acquisition of the necessary visual aids for the technical drawing room;

12. holding a methodological meeting on the organization of elective courses in high school;

13. meeting with the director "On the results of control";

14. methodological meeting "On the results of the participation of senior schoolchildren in regional and republican subject Olympiads";

15. meeting "On the results of control over the organization of independent work of senior schoolchildren";

16. thematic control "Game methods and methods of enhancing the cognitive activity of 9th grade students in the context of the modernization of the educational process";

17. midterm control "Results of pre-profile training of students".

The upbringing and developmental environment was also simulated in school with the help of another program, which we called "Abilities and Talent". Without explaining it in detail, we will illustrate the content of the program with several events:

1. Methodical meeting "Improving the forms and methods of working with gifted children".

2. Methodical meeting "The role of pedagogical diagnostics of students' abilities in the work of a teacher".

3. Conducting a pedagogical council "Eschew obfuscation, espouse elucidation".

4. Involvement of students in art groups, sports teams.

5. Competition "Student of the Year".

6. Competition "Hello, we are looking for talents".

7. Lesson for parents "The role of play in the life of a student".

8. Meeting with the director "On the progress of the implementation of plans for working with gifted children".

9. Reports of teachers on the results of work with gifted children. 
10. Classroom-generalizing control in high school "The role of pedagogical diagnostics as a means of studying the creative abilities of schoolchildren".

\section{Results}

In fact, the above fragments of programs for working with teachers reflect the process of modeling the upbringing and developmental environment. As the analysis of plans showed, the most important quality of the created environment was its humanistic orientation.

This is evidenced by activities of a personality-oriented nature, involving reliance on the interests and abilities of students. The most important characteristic is also the richness, the vastness of the environment, which is necessary for students' personal choice of the content and method of education in accordance with their needs and goals. This is facilitated by a variety of activities, both school-wide and in-class. In addition, various departments of the school, psychological services, administration, subject teachers, and homeroom teachers come to the aid of the children. A variety of forms, methods and means are also used, addressing both the game and career guidance work: competitions, assemblies, exhibitions, Olympiads, events, exhibitions, reports, methodological meetings. All this stimulates the possibilities of implementing a variable educational process both in terms of content and in terms of the used technologies.

To activate creative thinking with the help of gaming technologies, the initial skills for achieving personal satisfaction with the conditions and results of work are formed. Fulfilling a play role, entering into a conditionally real relationship with each other, the pupils acquire a little experience of creative knowledge of their possible future profession.

Action knowledge is knowledge of algorithms, sequence of actions, organizational charts. The research goals were to introduce high school students to basic graphic concepts and to the procedures for the functioning of these concepts. Here career guidance goals were also realized: students had to realize in which professions certain graphic concepts can be implemented, and attention was focused on the formation of students' skills to work with these concepts. Among such skills, there are the ability to identify (recognize these concepts in standard situations), the ability to independently use these concepts, to classify (combine) them on some specific basis, interpret and apply them in practice.

A game environment of this type stimulates in high school students not only interest in subjects, but also in professions and specialties of a technical nature that require graphic knowledge. Undoubtedly, such gaming technologies have an influence on the growth of interest in legal specialties, in design, drawing, in teaching professions.

\section{Discussion}

In the course of the research, the school used technical drawing Olympiads. Drawing contests and their exhibitions were organized by participants in design classes and decorative and applied art studios.

\section{Conclusions}

he study described above had a significant impact on high school students. By the end of the academic year, only $90 \%$ of them knew exactly which specialized classes they would choose, and more than $50 \%$ knew what profession they would learn in the future. This is evidenced by statistics. Tables 1-3 shows the statistical data on the impact of the environment on the formation of students' readiness to choose a profession in modeling. 
Table 1. Interest in technical professions.

\begin{tabular}{|c|c|c|c|c|c|}
\hline \multirow{2}{*}{$\begin{array}{c}\text { Task } \\
\text { No. }\end{array}$} & Total answers & \multicolumn{4}{|c|}{ Average score for each task } \\
\cline { 2 - 6 } & $\mathbf{1 5 8}-\mathbf{C}, \mathbf{8 2}-\mathbf{E}$ & \multicolumn{2}{|c|}{ C (before), E (before) } & \multicolumn{2}{c|}{$\mathbf{C}$ (after), E (after) } \\
\hline \multicolumn{2}{|c|}{$1^{\text {st }}$} & 1.7 & 1.1 & 2.1 & 3.4 \\
\hline & $2^{\text {nd }}$ & 1.7 & 1.2 & 2.2 & 3.5 \\
\hline & $3^{\text {rd }}$ & 1.8 & 1.2 & 2.3 & 3.3 \\
\hline
\end{tabular}

Table 2. Data on the awareness of students in the field of technical professional activities.

\begin{tabular}{|c|c|c|c|c|}
\hline Total answers & \multicolumn{4}{|c|}{ Average score } \\
\hline \multirow{2}{*}{$158-\mathrm{C}, 82-\mathrm{E}$} & $\mathrm{C}$ (before) & $\mathrm{E}$ (before) & $\mathrm{C}$ (after) & $\mathrm{E}$ (after) \\
\cline { 2 - 5 } & 1.45 & 1.4 & 2.2 & 3.6 \\
\hline
\end{tabular}

Table 3. Data on activity forms in the field of technical activity.

\begin{tabular}{|c|c|c|c|c|}
\hline Total answers & \multicolumn{4}{|c|}{ Average score } \\
\hline \multirow{2}{*}{$158-\mathrm{C}, 82-\mathrm{E}$} & $\mathrm{C}$ (before) & $\mathrm{E}$ (before) & $\mathrm{C}$ (after) & $\mathrm{E}$ (after) \\
\cline { 2 - 5 } & 1.25 & 0.8 & 1.9 & 2.9 \\
\hline
\end{tabular}

The analysis of the results indicates that the dynamics of the development of the level of readiness to choose professions associated with technical specialties turned out to be significantly higher in the experimental group, which indicates the effectiveness of the influence of the conditions we modeled.

\section{References}

1. L. Zheldochenko, O. Nikolenko, E3S Web of Conferences 210, 22001 (2020) https://doi.org/10.1051/e3sconf/202021022001

2. A. Parshukov, A. Bril, S. Krolivetskaya, E3S Web of Conferences 164, 12012 (2020) https://doi.org/10.1051/e3sconf/202016412012

3. A. Mikhaylova, O. Kruchina, V. Skorobogatova, A. Drozdova, J Petrunina, E3S Web of Conferences 164, 12021 (2020) https://doi.org/10.1051/e3sconf/202016412021

4. O. Melnikova, S. Shuvalova, E3S Web of Conferences 110, 02104 (2019) https://doi.org/10.1051/e3sconf/201911002104

5. S. Ovchinnikova, A. Borovkov, G. Kukinova, N. Markina, E3S Web of Conferences 244, 01007 (2021) https://doi.org/10.1051/e3sconf/202124401007

6. A. Borovkov, S. Ovchinnikova, A. Lyamina, T. Zheludkova, E3S Web of Conferences 258, 06059 (2021) https://doi.org/10.1051/e3sconf/202125806059

7. E. Tsoraeva, S. Mezhyan, M. Kataeva, L. Hugaeva, T. Rogova, E3S Web of Conferences Vol. 224, 03001 (2020) https://doi.org/10.1051/e3sconf/202022403001

8. E. Tsoraeva, A. Bekmurzov, S. Kozyrev et al., E3S Web of Conferences 215, 02003 (2020) https://doi.org/10.1051/e3sconf/202021502003

9. S. Ovchinnikova, A. Borovkov, E. Schneider, D. Kalinichenk, E3S Web of Conferences 244, 01013 (2021) https://doi.org/10.1051/e3sconf/202124401013

10. S. Belyaeva, O. Belyantseva, N. Safonova, O. Vasilyeva, E3S Web of Conferences 33, 03021 (2018) https://doi.org/10.1051/e3sconf/20183303021 